\title{
Embodying the Trauma of the Somme as an Ulster Protestant Veteran in Christina Reid's My Name, Shall I Tell You My Name?
}

\section{Andréa Caloiaro}

\section{(2) OpenEdition \\ 1 Journals}

Electronic version

URL: http://journals.openedition.org/etudesirlandaises/5122

DOI: 10.4000/etudesirlandaises. 5122

ISSN: 2259-8863

Publisher

Presses universitaires de Rennes

Printed version

Date of publication: 29 June 2017

Number of pages: $77-92$

ISBN: 978-2-7535-5495-5

ISSN: 0183-973X

Electronic reference

Andréa Caloiaro, «Embodying the Trauma of the Somme as an Ulster Protestant Veteran in Christina Reid's My Name, Shall I Tell You My Name? », Études irlandaises [Online], 42-1 | 2017, Online since 29 June 2019, connection on 07 September 2019. URL : http://journals.openedition.org/ etudesirlandaises/5122; DOI : 10.4000/etudesirlandaises.5122 


\title{
Embodying the Trauma of the Somme as an Ulster Protestant Veteran in Christina Reid's My Name, Shall I Tell You My Name?
}

\author{
Andréa Caloiaro
}

University of Florida

\begin{abstract}
Christina Reid's radio play My Name, Shall I Tell You My Name? (1987) confronts the crisis of identity that the Somme offensive effectuated for First World War veterans in the North of Ireland. Interrogating the Somme as part of Northern Ireland's state-level political teleology, My Name exposes the hegemonic pressure that this claim put on veterans to be received as ideal embodiments of a too narrowly defined Northern Irish identity - the martial, male Protestant unionist. Reid's play depicts the longstanding ethno-national and gendered exclusions predicated by Northern Ireland's processing of the trauma of the Somme.

Keywords: Christina Reid, the First World War, Northern Ireland, Battle of the Somme, Embodiment, Trauma, Narrativization.
\end{abstract}

Résumé

Dans sa pièce radiophonique My Name, Shall I Tell You My Name?, Christina Reid aborde la crise d'identité qui affecte les vétérans de la Première Guerre mondiale ayant participé à la Bataille de la Somme dans le Nord de l'Irlande. Elle montre que la Somme fait partie d'une rhétorique téléologique perpétrée par l'État, et dénonce la pression qui pèse sur ces vétérans sommés d'incarner l'idéal d'une identité nord-irlandaise définie trop étroitement: l'homme protestant unioniste martial. La pièce de Reid décrit toute la série d'exclusions générées dans le Nord de l'Irlande suite à cet événement traumatique.

Mots clés: Christian Reid, Première Guerre mondiale, Irlande du Nord, Bataille de la Somme, incarnation, trauma, mise en récit.

\section{Dramatizing the First World War's remembrance in Northern Ireland}

Christina Reid's First World War memory play My Name, Shall I Tell You My Name? (1987) concludes with protagonist Andrew Smith reflecting on his solitude as a First World War veteran. At the play's close, following the Orange 
Order's seventieth annual Somme Day parade in Derry, he admits: "I'm the only one left from the Great War, and they want to honour me'." Andrew is Derry's last living survivor of the $36^{\text {th }}$ (Ulster) Division, Carson's men, who went over the top at the Battle of the Somme on 1-2 July 1916 at the cost of 5,500 casualties, 2,000 of whom died. But as he waits year after year for the British Legion's arrival for the commencement march, Andrew is utterly alone. Recently, he has disowned his last living relative, Andrea, a beloved granddaughter. Their parting was bitter; his granddaughter's choice to leave Northern Ireland to attend a London university, and more, to accept the marriage proposal of an Anglo-Pakistani, is in Andrew's eyes, a betrayal, both personal and national. To Andrew, Andrea has turned her back on a Northern Ireland for which he and his company have been mythologized as defenders, having sacrificed their lives at the Somme in 1916.

Written in Reid's words, "for radio, [...] for voice", My Name was first broadcast by the BBC in 1987. The moment was significant. By the 1980s, the few Great War veterans who were still living came closer to passing away. Irish historians, authors, and the general public thus renewed an interest in collecting and reimagining Irish veterans' testimonies. The trend of recording and depicting those who bore witness to combat also coincided with an uptick in attending public commemorations of the Great War. Yet, given the sectarian violence of the Northern Irish Troubles between Protestant unionists and Catholic nationalists, war remembrances inevitably became political battlegrounds. For some, the Troubles seemed a repetition or permutation of the domestic, militarized political turmoil of 1914-1918 surrounding Home Rule, Partition, and the Anglo-Irish Treaty $^{3}$; that the Troubles' violence was, in part, conceivable as a re-manifestation of 1914-1922 is exemplified by the Enniskillen bombing of 1987, the year $M y$ Name first aired. On 8 November, the PIRA bombed Enniskillen's Remembrance Day ceremony. Though allegedly targeting the Ulster Defence Regiment leading the ceremony, the PIRA consequently killed ten civilians, one police officer, and wounded sixty-three others. The bomb also severely damaged Enniskillen's cenotaph honoring Irish Great War veterans. The PIRA's targeting a First World War commemoration resonated symbolically; in destroying the war's iconography and killing innocent commemorators, the act starkly reinforced to Irishmen and women how influential the First World War remained - and still remains - to

1. Christina Reid, Plays: 1. London, Methuen Drama, 1997, p. 276. Subsequent references appear in parentheses in the text, and the title will henceforth be abbreviated to My Name.

2. Maria Kurdi, "Interview with Christina Reid”, The Brazilian Journal of Irish Studies. Vol. 6, June 2004, p. 212.

3. As Heinz Kosok notes, in My Name, Andrew reads the Troubles as an "event that to him is still the Great War". Heinz Kosok, The Theatre of War: The First World War in British and Irish Drama, Houndmills, Palgrave Macmillan, 2007, p. 57. 
Northern Ireland's and the Republic's claims to oppositional political, ethnonational, and religious identity and legitimacy ${ }^{4}$.

Irish domestic politics were not only deeply enmeshed with the First World War, but as Reid's My Name testifies, that war's consequent paramilitary violence, trauma, and memory would haunt Northern Ireland for decades. It was Frank McGuinness who first depicted that haunting in Observe the Sons of Ulster Marching Towards the Somme (1985), a ghostly drama which established the "memory play" as a useful genre for Irish playwrights writing on the Great War. Similar to Sons of Ulster, Reid's play delves into the troubled memory of a solitary, traumatized $36^{\text {th }}$ (Ulster) Division veteran in order to reach across the border's ideological divide and "examine the complexity, diversity, disturbance and integrity of the other side, the Protestant people $e^{6)}$. But what distinguishes My Name is how its medium of the radio carries the conventional content of the memory play. Throughout the drama, Andrew Smith's voiceovers emerge from the past and intertwine with the present, conveying his oscillation between two times which he experiences contiguously, 1916 and the 1980s. This vocal splicing has a particular dramaturgical effect: insofar as Andrew's beliefs have remained unchanged over the decades, his voice has a ghostly resonance, as if he ventriloquizes an ideological position no longer tenable ${ }^{7}$; Andrew's body may inhabit Northern Ireland, but

4. Adrian Gregory and Senia Paseta (eds.), Ireland and the Great War, Manchester, Manchester University Press, 2002, p. 6; Loughlin James, "Mobilising the sacred dead: Ulster Unionism, the Great War and the politics of remembrance”, ibid., p. 148.

5. A term coined by playwright Tennessee Williams for his play The Glass Menagerie, Williams defines the dramaturgy of the "memory play" as having a particular "freedom of convention" (xIx) [...], noting that "memory takes a lot of poetic licence. It omits some details; others are exaggerated, according to the emotional value of the articles it touches, for memory is seated predominantly in the heart. The interior is therefore rather dim and poetic" (3). The genre of the memory play originates with Williams, Harold Pinter, and Brian Friel, although the latter two authors may not ascribe this term to their own works. As Williams goes on to describe, the genre's conventions include heavy reliance on a protagonist's rather dim, poetic, and quite unreliable versions of the past often vocalized through monologues and ruminations. The dramas' sets are also minimal, drawing focus on the verbal content rather than the physical. These features are characteristic of Reid's My Name and two other Irish First World War plays, Frank McGuinness's Sons of Ulster (1985) and Sebastian Barry's The Steward of Christendom (1995). In these plays, memory is of traumatic events and loss associated with the First World War, represented by the trope of veterans as ghosts, or ghostly voices. For further commentary on the memory play genre, see: Tennessee Williams, The Glass Menagerie, New York, New Directions Publishing, 1999, p. XIX3; Attilio Favorini, "Some Memory Plays before the 'Memory Play", Journal of Dramatic Theory and Criticism, 22.1, 2007, p. 29-52.

6. Frank McGuinness, Plays, Volume 1, London, Faber and Faber, 1986, p. x.

7. This article's reference for assessing the sound effects of radio drama is: Dermot Rattigan, Theatre of Sound: Radio and the Dramatic Imaginations, Dublin, Carysfort Press, 2002. Rattigan's discussions of the affective function of sound are useful in assessing My Name's use of both distant-sounding voiceovers for Andrew's and Andrea's memories, and for the drama's symbolic, physical objects, like the recurrent sound of distant prison doors shutting (of Andrea's cell), which are also heard when Andrew is speaking. Andrew's voiceover effect is recorded at a distance (in terms of microphone placement). This not only creates a sense of "the past" in both space and time, but also produces a disembodied-type resonance to his voice; the aural affect this creates is as if his voice utters against his own control, and those utterances intrude into the present. Furthermore, splicing those utterances 
his mind occupies an Ulster of the Great War era. As such, he is the embodiment of a decades - long, state-propagated ideal - the Protestant unionist veteran of the $36^{\text {th }}$ (Ulster) Division ${ }^{8}$.

The men of the $36^{\text {th }}$ (Ulster) Division were justifiably mythologized into Ulster's Protestant Unionist and Orange psyche at a moment when in the minds of those who were either wounded or lost loved ones, symbolized a legitimate sacrifice for the right to continued union. Like Sons of Ulster, Reid's play thus considers the effects that having to embody this ideal had on the Ulster unionist combatant by interrogating a crucial issue regarding wounded veterans like Andrew. If after the 1916 Rising, unionists anticipated the Somme as Ulster's trauma, its raison d'être (or Northern Ireland's "1916")", to what extent did this act predetermine how veterans themselves could process the Somme, and furthermore, how that trauma was inscribed into shared memory? The few critics who have written on My Name have noted that Reid's project is to deconstruct Northern Ireland's canonical processing of the First World War - in Claire Tylee's words, "the fixed masculine identity of the backward gaze, to the Somme ${ }^{10 "}$. But no scholarship focuses on this "backward gaze" as it is conveyed in My Name through the radio genre, nor how performing that gaze affects Andrew by motivating him to occlude broader parameters of Northern Irish identity, including women and non-ethnically Irish citizens in the United Kingdom.

Thus, through the lens of traumatology, this article will first argue that Andrew Smith's continuous, backward gaze to the Somme is effectuated by the state's tendency to appropriate the trauma of that event. Andrew becomes the consequence of what Jenny Edkins identifies as the traumatized subject being claimed or appropriated by political factions or institutions intent on legitimazing

with the sound of Andrea's closing prison cell doors accentuates what Rattigan calls the "extended signification" or "sonic significance" (173) of such objects: the sound effect accentuates the notion that Andrew is also "imprisoned" or "confined" by his own utterance, reinforced when his voiceovers carry those utterances into the play's present.

8. For sustained analyses of the sacrificial mythography ascribed to the $36^{\text {th }}$ (Ulster) Division in the North of Ireland, see: Jane G.V. McGaughey, "The Glorious First of July: The 36 ${ }^{\text {th }}$ (Ulster) Division at the Somme”, Ulster's Men: Protestant Unionist Masculinities and Militarization in the North of Ireland, 1912-1923, Montreal \& Kingston, McGill-Queen's University Press, 2012; Edna, Longley, “The Rising, the Somme and Irish Memory”, The Living Stream: Literature and Revisionism in Ireland, Newcastle, Bloodaxe Books Ltd, 1994; Thomas Henessey, Dividing Ireland: World War I and Partition, London, Routledge, 1998.

9. Succinctly summarizing this now well established premise, President Michael Higgins reiterated at the Abbey Theatre's 2014 Memory Symposium: "In the Irish context, World War One as a subject for commemoration poses the difficult issue of Ireland's divided, or even divisive, memories. It casts the Battle of the Somme, so central to Irish Unionists' identity versus the 1916 Rising”. Michael D. Higgins, "Of Myth-Making and Ethical Remembering”, Theatre of Memory Symposium, Abbey Theatre, Dublin, Ireland, 16 January 2014, Keynote Address.

10. Claire, Tylee, "Name upon Name’: Myth, Ritual and the Past in Recent Irish Plays Referring to the Great War", Aranzazu Usandizaga and Andrew Monnickendam (eds.), Dressing up for War: Transformations of Gender and Genre in the Discourse and Literature of War, Amsterdam, Rodopi, 2001, p. 276. 
their own prerogatives ${ }^{11}$; insofar as he is propagated as the ideal embodiment of the state's right to the union, My Name suggests that Andrew undergoes a secondary form of trauma: he suffers from the weight of an ideological narrativization of his own traumatic event, whereby he cannot escape that event's (re)occurrence. These reoccurrences, this tendency for Andrew to relive the past as the present, can be read through Cathy Caruth's notion that trauma defies the possibility of symbolic inscription and thus cannot be fully possessed - neither by the state, nor by the individual. Thus, insofar as Andrew has been inscribed as the Great War's sacrificial iconography, he is one of those traumatized who "carry an impossible history within them, or they become themselves the symptom of a history that they cannot entirely possess ${ }^{12 "}$ : Andrew cannot escape the extent to which he has been made to (self) propagate the hyper-masculine, martial, Protestant Orange veteran as the ideal embodiment of Northern Irish ethno-national and political citizenship.

In this context, it will also be suggested that My Name confronts an evaded issue in Northern Ireland and its theatre: that is, Northern Irishwomen's responses to the First World War, especially to the Somme. For Reid's play also focuses on Andrew's granddaughter, Andrea, and her effort to counter the predominantly masculinist purview which has narrativized the Somme into an exclusionary $t_{t e l o s}{ }^{13}$. Andrea not only speaks from the margin, but for the marginalized - and traumatized. Cast out by Andrew, imprisoned, and repeatedly strip-searched as a women's peace protestor, it is through her own traumatic experience that Andrea ultimately advocates for the inclusion of hitherto marginalized "histories", not only of the Somme, but of Irish and British national belonging. Through Andrea, My Name thus represents a paradigm for (traumatic) reconciliation that, in Caruth's terms, is predicated on "the way in which one's own trauma is tied up with the trauma of another, the way in which trauma may lead, therefore, to the encounter with another, through the very possibility and surprise of listening to another's wound ${ }^{14}$ ". As a Northern Irishwoman, Andrea represents a particular

11. Jenny Edkins, Trauma and the Memory of Politics, Cambridge, Cambridge University Press, 2003, p. 1.

12. Cathy Caruth (ed.), Trauma: Explorations in Memory, Baltimore, The Johns Hopkins University Press, 1995, p. 5.

13. As a Northern Irish, working-class Protestant woman, Reid develops in My Name a unique project to Irish First World War literature, for she prioritizes women's interrogations of the war. Her character Andrea's cognizance about the masculine control over the writing of history and subsequent shared memory of the First World War and the Somme aligns My Name with Reid's overarching theatrical project, which in Maria Delgado's words, is to give voice to "those whose experiences lie outside of 'official' history - particularly working-class women" (vIII). "Introduction," Christina Reid, Plays: 1. London, Methuen Drama, 1997. Moreover, in her references to the First World War, including those in Tea in a China Cup (1983), Reid's objective is to depict, as Claire Tylee points out, "women's responses to the ways in which masculine identity is constituted by violence and national identity by war". Claire Tylee et al. (eds.), War Plays by Women: An International Anthology, London, Routledge, 1999, p. 211.

14. Cathy Caruth, Unclaimed Experience: Trauma, Narrative, and History, Baltimore, The Johns Hopkins University Press, 1996, p. 8. 
mode of listening: one that both honors the Somme's trauma but indicts how her grandfather is inscribed as the Great War's iconography: like a ghost, his body carries a narrative made to endure past its time - in 1986, it is for Andrea, a hauntingly oppressive and anachronistic one.

\section{The Ulster Protestant veteran's trauma: the past as the present}

When the play opens, we hear the distant, echoed voiceovers of Andrew and Andrea, now both confined, Andrew to an "Old People's home in Derry" (252) and his granddaughter in Holloway Prison, London. Their past folds onto their present as they recollect the same memory, of " 1964 when Andrea was aged two and Andy was aged seventy-one" (253). The memory is Andrea's earliest, a poem entitled "My Name", one Andrew had taught her to express his unconditional love, and to walk and talk. From her prison cell, as therapeutic remembrance, Andrea draws portraiture (as her grandfather once did), illustrating him teaching her "My Name". The opening scene foregrounds the play's figuration of how human memory - regardless of referential accuracy - comprises for individuals a coherent version of the past. As Andrea states: "this should in truth be two drawings, not one. I didn't learn to walk and talk all on the same day. But that's how I remember it. Perhaps because the two events were joined in his memory" (254). But Andrea's awareness of memory's selectivity contrasts with Andrew's attitude toward the past.

The play's voiceover technique accentuates that contrast, for Andrew's words in 1986 sound like the recordings we hear from his past, in 1916; as if rehearsed, his present iterations rarely go beyond a well-rehearsed litany of unionist Orangeisms which were common in Ulster during the First World War. Like Sons of Ulster's Pyper, Andrew repeats in programmatic fashion that "Ulster" has "grown cold, [...] lies in rubble ${ }^{15}$ ". Reading the past as the present, he curses the passing of the 1985 Anglo-Irish Agreement in anachronistic, seemingly vetriloquized language; he longs for "Carson's army" (272), the men who were hailed at the Battle of the Somme for defending Ulster against Home Rule, and afterward, during the Irish War for Independence (272). Andrew's language reflects that in his mind, 1986 is reminiscent of the early Troubles, as the current sectarian conflict reminds him of when after Partition, "that scum rose up out of the Bogside" (268). But it is not just the threat of the Republic he resists, but of England. Evoking the paradoxical, Ulster Protestant unionist dictum of the war era, "loyalty to themselves alone $^{16 "}$, Andrew still envisions combatting republicanism via Parliament:

15. Frank McGuinness, Plays, Volume 1, London, Faber and Faber, 1986, p. 11-12.

16. Joseph Lee, Ireland, 1912-1985: Politics and Society, Cambridge, Cambridge University Press, 1989, p. 14. 
We beat the English Government then, we'll beat them this time round too. Anglo-Irish Agreement be damned! Lloyd George couldn't defeat us in 1920, and Maggie Thatcher won't defeat us in 1986 (272).

For Andrew, the First World War's domestic politics are still being fought in Northern Ireland, particularly, by Ulster Volunteer Force veterans like himself who "had signed the Ulster Covenant with his own blood" (272).

Such anachronistic ventriloquizations are in fact indicative of Andrew becoming a "symptom of history ${ }^{17 "}$ ". Indeed, the wounding, loss, and political crux of 1 July, 1916 return to Andrew like "flashbacks ${ }^{18 ", ~ a ~ c o m m o n ~ t r o p e ~ t o ~ I r i s h ~ G r e a t ~}$ War literature, especially memory plays ${ }^{19}$. But the poignancy of My Name's depiction is in the very desolation and symbolic confinement that these flashbacks effectuate. As Andrea is aware, her grandfather's attempt to legitimize his existence by re-enacting conflict and speaking its idioms manifests as a symptom of being politicized beyond his own control: he internalizes the identity he has been made to embody, and consequently, litanize ${ }^{20}$. He begins: "them were the days in France. Real men. Heroes. Ulster Protestant Orangemen. We'll never see their like again ... Joseph Sloan, Billy Matchett, Isaac Carson, Samuel Thompson, Hugh Montgomery" (255).

However, from her own isolation in prison, Andrea is motivated to bridge the divide with her grandfather by acknowledging that he cannot escape his legacy. In the 1986 present, Andrea's voice fades into her grandfather's as they recite in unison the names of Andrew's fallen companions from the $36^{\text {th }}$ (Ulster) Division:

The shared memory of these names has also come to Andrea as she draws and remembers her childhood. She has been mouthing the names that Andy taught her as he speaks. Andrea: ... "Hugh Montomgery, Frederick Wilson, Jame Elliott, John Cunningham, Edward Marshall ... A Litany of the Glorious Dead. [...] Just a handful of the five and half thousand Ulstermen who died on the first day of the Battle of the Somme. My grandfather went to hell and back when he was just twentythree years old". [...] Andrew: "A Glorious Victory. Their Finest Hour. An inspiration for painters and poets" (255-6).

17. Jenny Edkins, Trauma and the Memory of Politics, op. cit., p. 1.

18. Christina Coveney, "Christina Reid Obituary", The Guardian, 5 June 2015.

19. As they are in My Name, flashbacks and/or appearances of ghosts linked to prior events of violence and the First World War are tropes in McGuinness's Sons of Ulster and Sebastian Barry's The Steward of Christendom.

20. For the most recent, comprehensive analysis of the performative and cultural parameters of the martial, Protestant unionist, Northern Irish male identity, see: Jane McGaughey, Ulster's Men: Protestant Unionist Masculinities and Militarization in the North of Ireland, 1912-1923, Montreal, McGill-Queens University Press, 2012. 
As Claire Tylee avers, the associations with their incantation would not be lost on an audience of either the Republic or Northern Ireland ${ }^{21}$. The litany is reminiscent of Yeats's homage in "Easter, 1916" to those patriots who were shot without proper trial: "MacDonagh and MacBride / And Connolly and Pearse ${ }^{22}$ ". And in Sons of Ulster, Pyper commemorates his friends and lover who had fallen on the Somme in a similar manner: "Moore, Millen, Anderson, Mcllwaine ${ }^{23 "}$ ". Like Yeats and McGuinness, Reid is apprehensive about the potential occlusions associated with such a litany, while still iterating it to honor sacrifice. For Andrea's motivation to recite the litany is to comprehend a belief system which Andrew cannot so easily separate from the trauma he still feels. From the solitary confines of the prison, she acknowledges her grandfather's physical and ideological confinement, asking, "who does he talk to now, I wonder? Maybe he just talks. To the wall ... to the memories locked away in his old tin box" (254); and later, as we hear Andrea's "prison door slamming in the distance", she withholds the emotion of suffering by confiding in her grandfather's resiliency: "I won't cry. I mustn't cry. Give me some of your fierce, proud strength, granda. Did you ever cry, I wonder, when there was nobody there to see? Perhaps you didn't dare, in case you could never stop" (262).

Andrea's remark is profound, and empathetic. While My Name eschews narrativizing the $36^{\text {th }}$ (Ulster) Division as heroic defenders against, in Andrew's words, both "Fenians" (268) and now "Maggie Thatcher" and the "Anglo-Irish Agreement" of her "English Government" (272), the play is justly empathetic to Andrew's suffering: like Sons of Ulster, Reid's drama shows that the Somme's loss affects the individual insofar as Ulster's soldiers and casualties became the singular, sacrificial mythography of soon-to-be Northern Ireland. Reid suggests that this subjection is the deep-seated psychological trauma which paradoxically enforces the compulsion for men like Andrew to reiterate that mythography as a kind of self-legitimization, or that of the State. Indeed, the very absence of resisting this mythos in Northern Ireland - in literature, especially by women - attests to its durability. For the unionist appropriation of the Somme as "victory", both tactically at the front and politically back home for Partition, left little room for outright dissent, or as Fran Brearton points out, for the Northern Irish to conceive of 1 July 1916 as anything but that "imaginatively powerful image of the sacrificial victim that permeates much Easter Rising literature ${ }^{24 ”}$.

21. Claire Tylee, "'Name upon Name': Myth, Ritual and the Past in Recent Irish Plays Referring to the Great War”, Aranzazu Usandizaga and Andrew Monnickendam (eds.), Dressing up for War: Transformations of Gender and Genre in the Discourse and Literature of War, Amsterdam, Rodopi, 2001, p. 284.

22. William B. Yeats, The Yeats Reader: A Portable Compendium of Poetry, Drama, and Prose, (ed.) Richard J. Finneran, New York, Scribner Poetry, 1997.

23. McGuinness, Sons of Ulster, p. 12.

24. Fran Brearton, The Great War in Irish Poetry: WB Yeats to Michael Longley, Oxford, Oxford University Press, 2003, p. 35. 
My Name evinces the fixity of that mythos when Andrew's voiceover reverberates as a ghostly return from 1968, when he brings Andrea to City Hall Belfast to teach her about Prinsep Beadle's commemorative painting, Battle of the Somme: Attack of the Ulster Division. The iconic painting depicts the Somme as a victory, reinforced by its inscription, which Andrew quotes: "one of the greatest feats of arms in the annals of the British Army" (256). As Andrea hears Andrew's "ghost" in the present, she draws the painting, consciously ventriloquizing its fictionalized rendition of "victory":

The officer is young, golden, angelic faced. [...] 'Fritz' is being taken prisoner ... top of the painting ... more to the left ... and another German soldier lies dying. Not there ... bottom left ... An Ulsterman walks away from the dying man ... he carries a bayonet. Blood-covered. He looks ... nothing. Blank. His eyes are wide open, but he looks blind. The officer is bathed in a golden light ... (257).

Andrea's attention toward "proper" rendering - as simulacrum - correlates to the soldiers' choreographically depicted action, focalizing on Ulster's predisposition to victory. In this moment, as "the past merges with the present", the play's temporal splicing enables the present, "adult Andrea" to recall her grandfather's retelling his actual experience at the Somme (257). He "got injured minutes after clearing the trenches", and his friend Billy Matchett died a "terrible death" from a wound turned gangrenous after three days in no man's land $(257)^{25}$. Through Andrea's literal redrawing and commentating, My Name limns the tension, or contradiction, between 1 July's individualized experience and its state narratization: however costly, the Somme was, and had to be, remembered as a victory. As Jim Haughey even ventures to conclude, "Beadle's painting effectively celebrates a defeat", and "like the Easter Rising, a defeat in Irish memory often becomes a synonym for victory ${ }^{26 "}$. Moreover, Andrea realizes that Beadle's Battle of the Somme underscores the masculinist impulse rendered in this defeatist "victory"

25. The grave sacrifice made by the $36^{\text {th }}$ (Ulster) Division on 1 and 2 July was significant, for four out of nine Victoria Crosses were awarded to the $36^{\text {th }}$, and they incurred 5,500 casualties and about 2,000 deaths. Unfortunately, as Philip Orr notes, amongst the backdrop of the 400,000 British soldiers lost to the Somme offensive, and given the way domestic politics anticipatively claimed the Ulster Division as their sacrificial dead, the individual soldiers were indeed the ones who paid most dearly. Ulster HQ let its troops traverse no man's land a little too soon, and the $36^{\text {th }}$ Division never received the support that other divisions, like the $18^{\text {th }}$, had received against the German machine gun fire. Orr thus points out that while touted as heroes back home, the private $36^{\text {th }}$ Division soldier on the front found out that, in fact, "he was not a hero; he was simply expendable". Phillip Orr, The Road to the Somme: Men of the Ulster Division Tell Their Story, Belfast, The Blackstaff Press, 1987, p. 200-201.

26. Jim Haughey, "'Up to Our Necks in Fenian Blood': Ulster Loyalism, Its Myths and the Somme in Christina Reid's My Name, Shall I Tell You My Name?", Publication of the Philological Association of the Carolinas, Vol. 20, 2003, p. 10. 
- Haughey notes how "Andrea, looking back now as an adult, realizes that the painting has also helped mythologize the Somme as Beadle celebrates the testosterone virtues of the Ulster Division ${ }^{27 "}$.

Reenacting those "virtues" by performing them sustains the Somme's mythos. Thus, Andrew's voiceover willfully imagines Billy Matchett as one of the soldier figures in the painting, as if the act keeps Matchett "alive" (258):

See that soldier there with the bayonet? Spittin' image of Billy Matchett. [...] Billy was the best Lambeg drummer the road had ever seen. The Orange Lodge paid for his headstone. [...] Done him proud. Billy's son, wee Billy, took over the beatin' of the Lambeg drum when he grew up. Carryin' on the name. Carryin' on the tradition. Which is how it should be. [...] And now, young Billy's dead too. Cut off in his prime like his father before him. Second World War. Dunkirk. Still, his son, wee Billy has stepped into his father's shoes. [...] Sound of the Lambeg drum. Andy caught in the memory. Go on, ye boy ye! Yer granda'll never be dead as long as you're alive! (257-8).

While Andrea even-handedly refrains from dismissing Andrew's account of Billy's allusively Williamite legacy ${ }^{28}$, as a woman, she looks apprehensively at Orangemen plotting Ulster's narrative as a men's history solely "about war" (259). She remembers Billy in the "Twelfth of July Parade" (258); before he finally died while marching, he would beat the drum until "the blood trickled over the tattoos on his arms ... "Ulster is British"; "No Surrender"; "Remember the Somme, Dunkirk, the Relief of Derry" (258) ${ }^{29}$. Billy's physical body testifies to a loyalist narrative spanning generations. With a body similarly decorated by war, Andrew tells Andrea, "medals is for men. The men go off to war, and the weemin' and children stay behind" (259).

27. Ibid., p. 10.

28. Andrew himself sings "We are the Billy Boys", an homage to Protestant William of Orange's victory over the Catholic James II at the Battle of the Boyne.

29. Reid's allusions here are numerous. The Twelfth of July Parade not only marks the anniversary of the 1690 Battle of the Boyne victory, which solidified the Protestant Ascendancy's position in Ireland for centuries, but the Orange Order began integrating 1 July 1916 as part of that commemoration, not least since the Somme Offensive's date coincides with 12 July on the Julian calendar. Likewise, the Relief of Derry (Siege of Derry), marks the beginning of the Williamite Wars of which the Boyne was later part. Finally, like Tea in a China Cup's depictions of portraits of Northern Irish soldiers of the Somme alongside those of Dunkirk during the Second World War, My Name conveys how the pride of volunteer service amongst many Northern Irish soldiers during the First World War carried on into the Second World War, becoming a linked legacy of unionist military history. As in the First World War, conscription was never imposed in either Éire or Northern Ireland between 1939-1945, and although Northern Irish attitudes toward participating in the Second World War were divided, 38,000 Northern Irish (including 7,000 women) volunteered for service - and after the evacuation of Dunkirk, Northern Ireland saw an increase in enlistment. See: Keith Jeffery, "The British Army and Ireland since 1922", Thomas Bartlett and Keith Jeffery (eds.), A military history of Ireland, Cambridge, Cambridge University Press, 1996, p. 7. 


\section{Voices from the margin}

Such parameters not only relegate women outside politics, but also men. The politico-religious positions of some Ulstermen - who have themselves suffered the Somme's trauma - are elided if they do not align with Andrew's Protestant unionism. Looking at a photograph, Andrea revises the litany of names to include one such man: "Edward Reilly, the only other survivor with my grandfather. His greatest friend ... before the war. After the war, Edward sent his medal back. They were together in the middle of the photograph, and he cut Edward out" (261). Andrew's elision is symbolic, an attempt to "cut out" or "reject" an undesired reality. He scorns:

Turned down his medal. Turned traitor. Canvassed for the Labour Party after the war. Made speeches against the government and the monarchy. Betrayed all the brave men who fought and died so that we could be British and free. [...] Catholic throwbacks. [...] What sort of name's Reilly for a Protestant family? Intermarried [...]. But it never leaves them. Popery. Bad Blood. Nationalism (261).

Acknowledging her grandfather's partial success at eliding history, Andrea admits, "I never knew that Edward Reilly existed until I was sixteen" (261). It is Edward's grandson, Eddie, who supplies her with "another version of the Battle of the Somme" (261), one apprehensive about "Ulster Protestant Pride", "Orange sashes", and its men being sent in first "over the top singing songs about the Battle of the Boyne and the Siege of Derry, as if the Catholic King James had been resurrected and was leading the German Army" (261). Yet as Andrea recalls, Edward also "mourned them" - Billy, Andrew, his entire company; Edward "survived and wept every time he told that story to his grandson" (262). But why this trauma deserves mourning is more complicated in the eyes of Edward and Andrea than it is for Andrew; the Somme signifies a post facto betrayal that Andrew might not, or cannot, admit to - that in part, his mythos is predicated on ascribing a utilitarian ideal to the $36^{\text {th }}$ (Ulster) Division.

In such circumstances, the play asks us: what can be done for those who cannot support such stringent parameters wherein men like Reilly and women like Andrea are given no place? Indicative of Reid's oeuvre, one way My Name suggests attenuating this dislocation - especially for marginalized women - is by removing oneself from Northern Ireland ${ }^{30}$. And this is what Andrea does. Andrea leaves Belfast for college in London to pursue her talent in art (inherited from her grandfather), and to live independently as her own mother never had the chance

30. As such, many of Reid's young, Northern Irish protagonists are emigrants like Andrea, including Eileen in The King of the Castle (1999) ; Sandra, in Clowns (1996). and Rose in The Belle of Belfast City (1989). 
to do while caring for Andrew, her father. Andrea's choice, however, devastates Andrew. He imagines it as a betrayal to his legacy. From prison, Andrea recalls how her choice wounded her grandfather, though she is aware of the supreme irony of his mindset:

Andrew: They're not like us over there. Andrea: He was hurt at me even considering that anything in England could be better than anything in Northern Ireland. It's one of those paradoxes of the Ulster Protestant Mentality - being more British than the British, but at the same time, believing that anybody leaving the Province for the Mainland [...] is letting the side down. [...] Betraying the cause (265).

It is the company that Andrea keeps in London, and the more circumspective view she develops toward war, Britain, and Northern Ireland whereby as a woman, she represents Reid's endeavor at "implementing cultural change $\mathrm{e}^{31}$ ". Andrea becomes engaged to her well-off landlord, Hanif, an educated British-Pakistani. At the university, they study war poetry together, performing an "improvised play about war" (267). Andrea soon comes to realize that aspects of her grandfather's Somme mythography are appropriated; she re-quotes Andrew's "Somme poem" - actually, Theodore O'Haras "Bivouac of the Dead" - which honors American soldiers who fell in the Mexican-American War, concluding, "I expect it's much the same, no matter what war you die in" (267). Andrea's realization speaks against Andrew's uncritical reliance on the Somme's scripted idiom; My Name suggests that its idiom is not only akin to an ostensibly oppositional sacrificial myth, the Easter Rising, but it is also an ironic endorsement of Britain's imperial warfare.

The real paradox Andrea begins to see is Andrew's blindness to the fact that his idiom speaks of Britain's "betrayal" in the First World War while upholding its saber-rattling; praising Thatcher's Falklands policy, Andrew tells Andrea right before he disowns her, "Britain rules the waves again. [...] If Maggie'd been Prime Minister when that scum rose up out of the Bogside, the Troubles would have been over in a day. She'd have sailed the big gunboats into Derry the way she did to the Falklands, an' wiped the Fenians off the face of the earth" (268). Soon after, as an Irish emigrant, Andrea experiences firsthand the violence of such neoimperialist mentalities pervasive in London during the 1980s. As an Anglo-Pakistani, her fiancée Hanif is targeted by a group of "skinheads [...] out celebrating the English Fleet sailing from the Falklands" (271). He is left mentally disabled, acutely paranoid about racist attacks. But Andrea remains faithful to him, returning to Belfast to ask for Andrew's blessing over their union. Upon realizing that

31. Imelda Foley, The Girls in the Big Picture: Gender in Contemporary Theatre, Belfast, Blackstaff Press, 2003, p. 70. 
her fiancé is part Pakistani, Andrew disowns her: "He’s an Argy! [...] A half-caste! A nig-nog! [...] Get back to England and keep your black bastard there with you" (271). His banishment is permanent. In this moment, the play correlates "Ulster's" ethno-national insularity to that of Thatcherite Britain. Both are denials of demographic realities, regressive senses of Northern Irish and British national identities, which Andrea hopes to revise.

Thus, as Andrew is picked up to be paraded for the Somme's "seventieth anniversary", the scene merges with the "sound of another metal prison door closing" (271), that of Andrea's cell in Holloway Prison in 1986. The door's reverberation not only reinforces the sense of closed-door segregation, ethno-nationally and ideologically, but also the abuse that Andrea undergoes as a prisoner - abuse that further incites her motivation to speak on behalf of the traumatized. In her last soliloquy, Andrea reveals her situation: profiled for her Irish accent (after recent waves of IRA violence), she has been unlawfully arrested, imprisoned, and repeatedly strip-searched by British police for participating in the Greenham Common Women's Peace Camp protests against nuclear basing. Yet, her former presence at Greenham was as personal as it was political. Invited by Hanif's sister, Andrea had envisioned (as she still does) the all-women's camp as a space for women to finally act - to both protest against another global war, and to commemorate those who have already fallen to warfare and imperially - minded violence. Andrea recalls confronting anti-riot police as she lit candles with other women for family members killed in Britain's wars. She begins to recite her grandfather's Great War litany and concludes by adding three names: "the other three candles were for Edward Reilly and my grandfather and Hanif" (275). As Tylee points out, "Andrea subverts her grandfather's litany [...] by adding new names ${ }^{32}$ ". She intends her protest to bring together voices from the margins: those of Greenham's anti-militarist women vying to protect their children's futures from war and conscription, those like Hanif who are denied nationality through racism - an analogy to Andrew's attitude in Northern Ireland - and, even soldiers like her grandfather, debilitated by British-unionist jingoism and masculinist militarism, which he himself has internalized ${ }^{33}$.

32. Claire Tylee et al. (eds.), War Plays by Women: An International Anthology, London, Routledge, 1999, p. 212.

33. Andrea is inspired to transform the protest into an impromptu commemoration with an elderly Englishwoman whose male relatives have been made casualties by the British Army. Lighting candles (as does Andrea to add to her Great War litany, Hanif, Edward Reilly, and her grandfather), the women walk toward the guards as the Englishwoman protests on behalf of her "nephew crippled in the Falklands", her "lover killed at Dunkirk", and her "father shellshocked at the Battle of the Somme" (273). With stark irony, which is Reid's indictment against British imperialism's inherent racism, the British Guards accuse Andrea of being an IRA affiliate simply because she has an Irish accent; they arrest her and imprison her at Greenham, where she is then sexually abused - another permutation of martial male misogyny (273-274). 
It is crucial to note when and how Andrea begins speaking for the margins. As Imelda Foley has suggested, Andrea's emigration "makes it more than clear that the only way out of a very sectarian, sexist historical morass is to get out. She configures change from outside, because it is impossible from within ${ }^{34}$ ". Yet, it is in London where Andrea undergoes forms of (para)military violence, racism, and sexual abuse that are reminiscent of those she left behind in Northern Ireland. My Name goes beyond indicting these ideologies, unbound by state borders; through Andrea, the play demonstrates how "listening to another's wound ${ }^{35}$ " forms what Jon Patočka calls a "solidarity of the shaken" - that is, those victims who consolidate themselves out of persecution (be it war or institutional violence) in order to resist or speak out against state-level power and coercion ${ }^{36}$. My Name poses cultural change as enacted by those, and amongst those, who have suffered by the state; as such, Andrea envisions (traumatic) empathy as a requisite for reconciliation. For Northern Ireland, the play proposes coming to terms with the fact that the First World War's exploitative mythography can be considered part of that war's posttraumatic legacy. Indeed, My Name exposes an issue which is only now beginning to be acknowledged: that propagating the $36^{\text {th }}$ (Ulster) Division's veterans as solely embodying a unionist telos may appropriate what was for many veterans an individual, traumatic experience, into a collective legitimization for the State - moreover, it is a State which has outlived the gendered and ethno-national boundaries associated with that telos.

For Reid, this crux of trauma and embodiment also has a biographical dimension. When Imelda Foley once asked her about the "ambivalence" whereby she depicts the Ulster Protestant psyche "like Frank McGuinness", Reid responded:

My grandfather was like that. When I asked him about the Somme he talked about valour, patriotism, loyalty. He wouldn't question it. He couldn't, because to question the war would have meant questioning his

34. Imelda Foley, The Girls in the Big Picture: Gender in Contemporary Theatre, Belfast, Blackstaff Press, 2003, p. 66. Elaborating on Reid's project in My Name to envision women's resistance to the enduring, masculinist control over the Somme's memory, she writes: "Reid's approach, however, is a search for a form that may define the lost lives of women who have worked to maintain the silence of the men of the Somme and their official historians maintained and defended for more than half a century. It is a silence that women have perpetuated, possibly against their will, a form of collusion that could never be described as 'feminist', a form of life that denies any kind of freedom" (67).

35. Cathy Caruth, Unclaimed Experience: Trauma, Narrative, and History, Baltimore, The Johns Hopkins University Press, 1996, p. 8.

36. Jon Patočka refers to the "solidarity of the shaken" in Heretical Essays, specifically with the First World War in mind. He goes on to write that "the solidarity of the shaken is built up in persecution and uncertainty: that is its front line, quiet, without fanfare or sensation even there where this aspect of the ruling Force seeks to seize it". Jon Patočka, Heretical Essays in the Philosophy of History. Eds. J. Dodd, transl. E. Kohak, Chicago and La Salle, Open Court, 1996, p. 135. 
peacetime allegiances too, King and Country, God and Ulster. Everything he'd lived and survived $b^{37}$.

In My Name, Andrea expresses a similar sentiment about Andrew:

You must have moments of doubt. You must have. You're stubborn and you're proud, but you're not a fool. Loyalty. Patriotism. Them or Us. You daren't question what all that has done to you, because once you question even a small part of it, you end up questioning it all. And to do that, would be to negate your whole life. Everything you've lived and survived by (275-6).

In fact, reading Andrea's sentiment through traumatology revises the former consensus that Reid casts Andrew as rather "one-dimensional ${ }^{38 "}$. Andrew's onedimensionality should be read as representative: he metonymizes the effects of being claimed by, and made the mouthpiece for, a particular (traumatic) mythography. As such, Reid raises a concern pertinent to current attempts at reconciliation, as Ireland enters its decade of centenaries: to what extent has individual, private processing of trauma been influenced or appropriated by sociopolitical exigencies? For as the play suggests, if Andrew cannot mourn his former best friend Edward Reilly, it is because mourning Edward - a traumatized objector - would be a "betrayal" to Ulster. Consequently, Andrew's friend remains part of an impossible history within himself, persistently returning to him, hauntingly. But it is Andrea who brings us to this insight. She actively disembodies the conception of masculinist, ethno-nationality Andrew is locked in by acknowledging and legitimizing contiguous narratives of trauma: that is, Edward Reilly's own conception of how the Somme should be processed, a conception which has been occluded by the same quasi-imperialist, militarist ideology that Andrea, as an Irishwoman, and her Anglo-Pakistani fiancé experience firsthand.

Andrea's last attempt at reaching out to Andrew thus reflects how reconciliation is actuated by recognizing the contexts wherein "one's own trauma is tied up with the trauma of another ${ }^{39}$ ". She imagines the well-known moment when "one Christmas Day, during the First World War, a group of British and German sol-

37. Imelda Foley, The Girls in the Big Picture: Gender in Contemporary Theatre, Belfast, Blackstaff Press, 2003, p. 60.

38. This is the term interviewer Maria Kurdi uses to refer to what she views as the stereotypical depictions of Protestant loyalist Ulsterman in Reid's plays (207), while critic Jim Haughey refers similarly to the "didactic nature" of Reid's dialogues (12). However, this article suggests that the portrayal and dialogue of such Ulsterman is Reid's way of signifying the way a particular loyalist narrative - or any ideology - is often ventriloquized, even if unwittingly. Reid's dramatization of ventriloquy highlights the pressure placed on veterans who have been heroicized by the state; as Andrea points out, for such men, having any moments of doubt or questioning would mean negating their senses of survival (256).

39. Cathy Caruth, Unclaimed Experience: Trauma, Narrative, and History, Baltimore, The Johns Hopkins University Press, 1996 , p. 8. 
diers called a halt to the fighting, and declared a truce" (276). Thinking of her separation from her grandfather in the 1980s present, Andrea's reflection analogizes the necessity of finding common ground to reconcile ideological differences through diplomacy, especially in a decade rife with sectarian violence amongst the paramilitary forces of Northern Ireland, the Republic, and England: "there must be an hour, a place, where he and I can meet. A piece of common ground. A no-man's land. If it's possible for strangers, then it's possible for us" (276). She anticipates the attitude toward reconciliation needed to move past ideological confinement, both within the United Kingdom and toward the Republic: "To make peace", she concludes, she and her grandfather must move beyond mere tolerance; they must acknowledge each other's suffering and say, "I love you, even though I have grown to loathe everything you believe in" (275). Ultimately, Andrea acts out Reid's vision for a mode of reconciliation predicated on "listening to another's wound ${ }^{40}$ ", that is, enacting empathy by acknowledging the possibility - and legitimacy - of another's trauma. And, as Northern Ireland and the Republic move further into a decade devoted to commemorating warfare and trauma, My Name represents literary narrative's place in offering "a new mode of reading and listening ${ }^{41}$ ", within and across borders. 